\title{
Study of Ethics and Human Rights in Western Schools and Discourse of Political Islam
}

\author{
Mahya Rafiee Bandari ${ }^{1}$ \\ ${ }^{1}$ Department of Education, Faculty of literature, Shahid Bahonar University of Kerman, Kerman, Iran \\ Correspondence: Mahya Rafiee Bandari, Department of Education, Faculty of literature, Shahid Bahonar \\ University of Kerman, Kerman, Iran. E-mail: kourosh.asayesh@gmail.com
}

Received: October 8, 2016

Accepted: October 18, 2016

Online Published: January 10, 2017

doi:10.5539/res.v9n1p130

URL: http://dx.doi.org/10.5539/res.v9n1p130

\begin{abstract}
According to the invariance of many provisions of Islamic teachings on the one hand and existence of interest on the other hand, political Islam by interpreting repeated primary and secondary rules meaning tries to strengthen Islamic state.

Therefore, moral meaning and discourse of human rights concepts such as freedom, equality, justice and ... is different from many traditional and political jurists and implications in the moral bases at west (Kant's own good school and school of profitability) and Western human rights. Accordingly, in this paper, we try that according to the views of Imam Khomeini as the founder of political Islam in Iranand Ayatollah Mesbah Yazdi as one of the most important theorists of this discourse that have different ideas about ethics and discourse concepts of human rights and explain the position of political Islam with regard to the domestic interests in the west moral education with an emphasis on Kant's own good and utility schools and moral concepts of human rights.

Now the question in study is that according to the ethics discourse of human rights concepts and some basic precepts of Islamic teachings, whether political Islam and more has functionality the consistency with Kant's ethics or due to the use of evidence deemed, is consistent with profitability school or not or finally by rejecting the aforementioned schools, offers a third way? And according to his moral system in contrast to the concepts of human rights discourse, provides what position?
\end{abstract}

Keywords: political Islam, Inner Fairness School, School of Profitability, ethics and human rights

\section{Introduction}

The moral and ethical issues in every community and school system has always been of interest from time immemorial to philosophers and scholars.

Political Islam and human rights in discourses in both Iran and the international community can influence and has great importance due to their lack of ethics and morality cannot be innocent there.

Iran claimed political Islam as the dominant discourse and hegemony in the strategic planning and justice for the people of our society and the international community leading to implementation of virtue, dignity and happiness in this world hereafter. In addition to the promotion of virtue and human dignity in the world, it is aimed to meet the spiritual needs of human happiness in the hereafter and strives.

Since they provide a coherent model for explaining the interaction between the elements of religion, morality and the rights and obligations in each community, it is could be one of the most fundamental issues to be considered. Political Islam, like every government needs a coherent theory and model in this regard. In this paper, a brief explanation of the discourse of political Islam and school of "intrinsic fairness" to the outcome of ethical theory to explain these two schools.

\section{The School of "Inner Fairness" and "Utilitarian": Absolute and Relative}

A group of philosophers and scholars care absoluteness of "good and evil" and some others believed morality and consider it as proportional elements. The first group believes that "good and evil" and ethics of the good ones and the bad ones consider do's and don'ts in every time and place and circumstances in each community remain constant and unchangeable. 
The second group, who believe in moral relativism and moral principles of "good and evil" has something mutable and relative in different places and communities. In the first group known as the school of "own good" Immanuel Kant (1724-1804 AD) more than other philosophers in modern times discusses about the deliberate moral absolute.

In this regard, Kant believes that moral values are absolute and has no exception moderate morality, but in no case do not accept change. Actions such as "fulfilling that promise" and "honesty" for all human beings and in any circumstances has proved to be unique (Kant, 1990, pp. 62-63).

He has basically good practical and moral responsibility. First and second, he optionally complies with the intention of doing the job. "Kant believes that only morally admirable action is choosing to have duty to be performed or to be made ... But the choices provided on his view should be the appropriate task as consistent. This means disagreement with that viewpoint, or by which viewpoints are not prohibited" (Bruce Oni, 2002, pp. 29-30).

But in the school of "utilitarianism", thinkers such as James Mill, Jeremy Bentham and John Stuart Mill are theorists who have addressed actions based solely on benefits and losses under the heading of good and bad things. The benefit synonymous with "good" and harmful synonymous with "bad" is replaced.

Therefore, the current lead is the most profitable in the actions of "good" and vice versa. Accordingly, for example, theft, betrayal, lies and oppression, a society will benefit from these actions and will be all good. And as honesty, integrity makes society as worse off and the actions "obscene" will be justified. The school of utilitarianism with all things are relative and proportional to absolute moral principles.

Philosophers of this school believe that it should be among the various possibilities in each case against us and must be instantaneous to choose the greatest benefit to the most people. That means that if something causes the interest and benefit to society, good and bad is not taken into account and it is moral care.

Interest income leads moral evil people. So if the school of "own good" by Kant is "absolute" moral principles in all circumstances and believes, it will be based on proven principles and absolute conscience of mankind to achieve the utilitarianism at odds with the theory of relativity and school.

\section{Explaining the Political Islam and Its Moral System}

Islamic-Shiite political Islam is aimed to return to one's roots and the emphasis on tradition and religion in contrast to the pro-Western discourses and signifiers of the modern discourse articulated around the central signifier of the "Islamic State" under the leadership of "absolute guardianship of the jurisprudent". Imam Khomeini, Ayatollah Mesbah Yazdi, Ayatollah Javadi Amoli and many administrators and jurists in the Islamic Republic can be mentioned as representatives of this discourse.

In explaining the moral of this discourse, it can be derivative such as "right" and "justice" called on the religious orders due to the significant moral person obliged to do so and affairs and actions.

But these things are proper in this moral discourse that can be divided into two categories: 1) ethics basics, and 2) ethics evidences.

Fixed and immutable moral principles are there, but morality in regard to time and place depends on different conditions and varied relative according to the evidence "expedient" to attract the interest and disposal losses of the state and Islamic society.

For the creation and preservation of the "Islamic State", it is based on the teachings and truth of Islam along with religious practices, such as the most "fundamental principles and absolute good" in this discourse. These principles are constant and do not change and relativity in that way. Because in the light of the "Islamic State", it can be spoken worldly and otherworldly bliss is achieved and will ultimately reach ethical principles as what is relative and changing instances and cases are due to various political and social conditions in time and space and cleaned joins. Making sense of moral and religious duties with such different interpretations in the field is important.

Ayatollah Mesbah Yazdi with his "theory" holds that: "All of absolute moral values and a matter of contract cannot be accepted in which some of moral judgments show the relative sense and are subject to certain conditions" (Mesbah-Yazdi, 2007, p. 161). According to them, some absolute propositions and some are restricted and relative. Ayatollah Mesbah in explaining the differences between these two sets of rules, noted some of them rooted in human nature and unconditionally are linked with the main purpose and ultimate human which is extremely desirable because human nature is unchangeable and the values on which they are based are the immutable principles and values in the view of Islam (Mesbah-Yazdi, 2007, pp. 164-165). He also states that 
the ultimate perfection of human beings is in proximity to God and to explain and evaluate the ethical concepts and issues requiring the tenets of religion (belief in God and the Resurrection and of revelation) and the content of revelation and religious orders. In this case, under any circumstances, not only the religious beliefs and moral orders separate religion, but religion is not necessary in any condition.

He says that in determining the ultimate goal of ethics and standards of valuation and actions in the diagnosis and determining the value, counter value and indifference show beliefs and religious injunctions as desperately needed (Mesbah-Yazdi, 2007, p. 188).

Imam Khomeini's overall strategy of political Islam is making sense of "politics", applied ethics and politics in union with one another item: Islamic law, political effect and Islam as a political religion in a religion that everything is politics even worship to Islamic and ethical precepts (Khomeini, 1999, Vol. 13, p. 130) with humans left to itself in paragraph passions and material needs that will be captured in any educational system and even politically correctness that would be incapable of nurturing spiritual dimensions. However, the basis of everything is spirituality noticed and the reform and development of the human dimension take all other problems that will be solved. The problem of the world today of the ethical dilemma is not resolved and the world will go downhill fall. So political Islam in school jurisprudential profit and profitability is as a result of many governments to consider and act on it, so the location is not given.

Since the Islamic government is under the leadership of the Supreme Leader to the fleeting interests of this world and the Hereafter and gaining global attention to the spiritual and eternal happiness is for the reflected man.

So many of the benefits in the Islamic government is like other governments that could use it to achieve as material gain in political Islam.

For example, it is possible to increase tourism revenues to ignore some of the Islamic laws and rules to cover relations between men and women and tourists established in casinos, cabarets and nightclubs and indulgence and hedonism, and so on.

Imam Khomeini during the Iran-Iraq war achieved results and win sub-targets and says: "By the way, unless we have forgotten that we fought for duty and the result has been a branch ... We all have a duty not assigned to guard duty and as a result ..." (Khomeini, 1999, Vol. 21, p. 284).

Islam, unlike utilitarianism according to the Imam Khomeini School is a school of material-spiritual material and the attention is spirituality inevitable, because it is spiritual basically. Politics without ethics is fundamentally incapable of guiding people and their true interests.

The prophets and saints want nations, society and people lead the way to take in all materials which for humans is imagined from the community to be considered (Eslami, 2002, pp. 232-233).

Ethical school of "own good" as well as the ability to decide for all individual and collective behavior does not tolerate all the do's and don'ts and cannot create consistency with political Islam's moral system. In Kant's moral system, it has moral duty requirements of a rational as any prospect of reward or punishment that we do not practice it. Kant has "good will" and the source of all goodness and put assignment intentions and good faith to the only basis for moral action, not a reward or punishment.

In this way, internal affairs and sensual moral good and evil plans and what counts with standard measures of good will is considered. Before the court of conscience, goodwill value is not the external manifestations of Will (Ghorbannia, 1997, 1998, p. 329).

Therefore, since political Islam cannot be absolute in the Kantian ethical decision making and behavior to pack and go with utilitarian ethics, it is seeking material benefits and influence of public opinion with no bounds and the alterity of the other seeks to provide a moral system where ethics based on Islam is the receptor complex and intertwined network of absolute fixed principles as examples of relative variables, "objectives" and fundamental objectives obtained by understanding the conditions of time, place and politics and social terms. For this ethical system, combining sophistication and ease is provided.

To seek "rationality" and "realism", Islamic ethics requirements are particularly the complex the nature of individual and social actions with multi-dimensional and complex structures and systems and on the other hand, this system of morality is organic and organized and personal perception and social status of different absorption is capable of good and evil moral right to act as an effective fighting (Mahmud, 1998, p. 154).

After evaluation criteria in accordance with the principles and ethics of Islam discourse signifiers, it has "closeness" to the God Almighty sometimes and as good approach and without faith in God, it is not possible to 
say the origin and limit the moral values of Islam as the faith. This means that the value system is valued only for people that are derived from faith in God.

In this regard, Imam Khomeini says that "Islam is political as moral judgments. The judgment is given in the Qur'an that believers are brothers and this is a moral imperative for a social decision as a political decision" (Khomeini, 2008, Vol. 13, p. 130), so it is important in political Islam for objectives include:

Islami government formation and retention for compliance and implementation of Islamic laws for religious practice to achieve perfection and happiness in this world and the hereafter, and my prayer life and nearness to God, thus school and ethical should also must in order to achieve these goals.

\section{Investigating the Role of "Absolute Guardianship of the Jurisprudent" and the Effect of "Expediency" on the Moral System of Political Islam}

Imam Khomeini, the supreme leader had a role in society and morality in relation to believing "creational guardianship" and view the maximum, and the provincial government and the provincial government jurists along the prophet (pbuh) and the Infallible Imams put this (Khomeini, 1968, p. 6).

Leading the people was aimed to achieve perfection and welfare and religious and spiritual laws described as "interest" and explained by the supreme leader.

The jurists have noted the Velayat as fundamental element because, in the absence of no one, but the Supreme Leader does not have: 1) the law is the same jurisprudence, 2) justice of ideological and moral perfection is required.

In addition, the supreme leader has the highest degrees of virtue and competence as well that due to these unique features, their positive state dictates issued the judgment.

The actual material and spiritual is moving towards perfection and happiness in this world and the hereafter considers it.

Political Islam follows the "meta-discourse" of Islam in which people believe that God knows better than other materials to the results of the real materials and this matter does not occur unless the practice of law and the rights of religious and supreme command absolute authority and that political Islam also has the highest authority.

That is why Ayatollah Mesbah-Yazdi believes that "high-ranking officials in any of the other systems of moral competence has leadership in the Islamic Republic of Iran" (Mesbah-Yazdi, call the teacher to the questioned young people, p. 165).

That is why political Islam and the implementation of duty of religious orders placed from its main objectives and duties of the result and win priority. Law becomes a practical philosophy entering the elements of time and space on Ijtihad in Islamic government opening a new chapter.

The same element creates interest. According to the slab-interest earning benefits and harm can be used in different situations.

\section{Outcome of Human Rights in Political Islam}

Since no human knowledge has capacities allowing him to claim the most noteworthy discovery as possible purpose for him.

And according to the desired final morally acceptable in political Islam and determining man, first principles of anthropology in political Islam and human rights are discussed.

\subsection{Anthropology of Political Islam and Human Rights}

The purpose of man life in the discourse of political Islam is human beings in this material world, but the main purpose of life and the spiritual dimension is human life that is centered by eternity.

People in the world has come to the aid of spiritual growth and spiritual progress to eternal bliss and immortality that God's nearness has achieved.

So God created man in his vicegerent on earth, puts up during the stages of spiritual growth and joined to the Lord in the hereafter. But in the discourse of human rights, it is considered as a "source of knowledge" and meaning of "self-axiomatic" noting that the manifestation of humanism and the human need aid and assistance paranormal and metaphysical consequences.

Discourse of human rights has the owner and the right to freedom and has the skeptic in all things and nature, the wisdom and vertical humanity and meaning of the secular and democratic condition. 
In the face of political Islam religious man, worship and duty is dependent on extra-human and theological guidance and submission to the will and pleasure of God under such circumstances as a person close to perfection and happiness that can capture "Caliph of Allah", "Yadu'llah", "the same God" and "God's permission" (Imam Khomeini, 2006, p. 331), otherwise more fierce and inferior to other animals. For the man in the discourse of political Islam, it can be considered as "the knowledge".

But in the discourse of emancipation from the fetters of supernatural and authenticity with its finding has the "subject" and everything to become the recognized "object". Man for his perfection, it is not beyond this physical earth in search of perfection and its happiness as needless to seek relief and grace and dominion over nature, and answering their questions and concerns.

So on both a human discourse, it can be considered as the successor of God on earth, but a succession of very different ways is aimed to achieve in our otherness.

\subsection{Freedom in the Discourse of Political Islam}

While Imam Khomeini explained it as axiomatic evidence of freedom, he knows and believes that "freedom is not an issue which is defined. Free people has their opinion and required no work (Khomeini, 2001, p. 11), but also implies freedom based on the provisions of the holy legislator making sense that the nation is free by law".

Freedom should be limited to religion and it is not detrimental to the nation and not a conspiracy against Islam Freedom and does not mean to sit down and talk, freedom of law, freedom of religion and our country about Islam in which Islam does not harm our constitution knowing the religion of Islam (Khomeini, 2001, p. 12).

Ayatollah Mesbah Yazdi in explaining it said that: "If religion is for this, everyone will behave in any way. What is the status of religion? And where is the place of religion? There are limits on freedom of religion and the law means other than humans. After that it is said that freedom of speech is high above religion" (Yazdi, 1999, p. 209).

He also knows the freedom of two types or "legitimate" or "illegitimate" condition with a religion and the law has prescribed it and not against it, but the freedom is illegitimate and religion prohibits it. After this type of restriction and prohibition of the right to freedom of religion, it is forbidden (Yazdi, 1999, p. 210).

The same issue can be said for unlike political Islam in human rights, religion and sharia scholars consider legal inferences as an expression of freedom and determining the limits and criteria, because, as mentioned earlier, if the creation and acceptance of the above conditions is considered, most of the good and happiness of human beings in this world and the hereafter can be achieved.

Freedom of expression in the "conspiracy" or "detrimental to the nation" is not there, otherwise it will be buried (Khomeini, 2001, pp. 64-100), but the freedom of expression can be true conspiracy and or be considered as murder that he should bury it?

The recognition is considered as sovereign Islamic state as the supreme leader. Since the Supreme Leader Imam is the only legitimate successor of vice judgment, the right and wrong and conspiracy and intrigue of a healthy and constructive criticism is discussed.

\subsection{Rationality and Individuality in the Discourse of Political Islam}

While human rights in intellectual framework gives meaning, commitment and respect for human dignity and freedom is only based on human rationality situations. Rational individualism has narrow area on the practices and religious edicts and "individual rights" take precedence over religious obligations and "social concerns".

But in the face of political Islam, human society took precedence over the individual and even to maintain the Islamic system and the human individual can be sacrificed. While four sources of evidence is the reason of jurisprudence in Quran, Sunnah and the consensus is considered, however, it should receive particular attention in a way that relates to the discovery of intuition, wisdom and insofar authority of Scripture and tradition not in confrontation and conflict with the Quran and Sunnah. The human intellect is needed to guide the supernatural forces and book the Koran sayings of the infallible God's commandments as the most complete collection of laws and ordinances and ability to meet all human needs (Khomeini, 1979, p. 33). Due to the necessity of homework human and divine laws, it should be without any doubt, submit orders and fatwas is for the great jurist to carry out their orders and complete the assignment.

Each item shall have discretion not to non-essential order in all forms of worship, dealings, even desirable and chanting or emulator or cautious as long as precautions know that the less one knows; after practice layman is not familiar with the precautions and there is no imitation with detailed Pops (Khomeini, 2006, p. 9). 
The "Vacuum Zone" deals with human reason in its self-manifestation very limited.

Finally, we can say that the discourse of political Islam in the alterity of the human rights discourse is based on humanism and rationalism to fatten divine revelation and scriptural arguments in opposition to abstract rationality and discourse markers based on the Quran and the Sunnah meaning.

And since everything is in the hands of God, no one from the right holder, therefore, the true identity of man is found himself in front of God.

In this case, everything will be important, but not God himself.

\section{Conclusion}

Political Islam is a religious system in your target in addition to the well-being and security of the society and the Islamic nation and Islamic society is in compliance and enforcement of laws towards spirituality and religion of ultimate perfection, which is getting close to God and moral systems offering a unique model that the laws and commandments for the development of all aspects of human existence is the true perfection and happiness and respect for the sovereign materials forming him.

Therefore, human self-rule in the West are considered alterity and the theory of discourse is in the light of the spiritual interests of religion realized in this discourse of the primary objective.

In this system, the supreme leader and expert personal piety and justice and jurisprudence is consists of two elements to understand the terms and conditions of the day, drawing morality and Islamic society and government policies improving evolution of man coming true and move in the direction and authority of divine revelation after the final favorable ethics in political Islam as nearness to God.

For that, a deep understanding of presence and immediacy of existence belongs to absolute perfection, which makes actions have moral value.

So perfection in nearness to Allah Almighty isstated in the shade affiliation and full compliance will be achieved soon and the denial of sensuality is in obedience to God and it has the worship of the most important ways. Political Islam tries to collect virtue and moral expediency founded in addition to being for all people planning to cover both interest and task-oriented focus is on tasks that are observed. That is the fact of unfolds between virtue and moral expediency.

At the same complexity of the flexibility of this school, it is considered as traffic police officers and intrinsic Kant theory apart from how to explain the true intentions as the "good" and "duty" condition and the meaning of slab interests in the circle of discourse as worldly and eternal consequences and harm are trying to gain.

Fixed and variable manifestations of political Islam divides have moral principles and moral system has the capability, capacity and flexibility in different responsive and able circumstances.

But since the human moral system has "complete surrender" of duty, religious worship is keeping the commandments and task outcomes and have preferred rights, the refusal principles and concepts of human rights discourse is important (according to the views of Imam Khomeini and Ayatollah Mesbah Yazdi) investigating the exception with meaning of the provisions of assignments on the basis of religion.

\section{References}

Bayat, A. et al. (2002). A dictionary. Religious Thought and Culture Institute, Qom.

Bruce, O. (2002). Kant's moral theory. Qom: Book Garden Publishing.

Ghorbannia, N. (1997). Interpreter ethics law, the quarterly of review.

Imam, K. (1978). The supreme leader. Tehran: Amir Kabir.

Imam, K. (1999). Description of forty hadith. Tehran: Adjusting and publishing works of Imam Khomeini Institute.

Imam, K. (2001). Freedom of thought. Tehran: Institute for the Works of Imam Khomeini sawing.

Imam, K. (2006). Anthropological thought. Tehran: Institute for Compilation and Publication of Imam Khomeini's Works.

Imam, K. (n.d.). Sahifeye Noor. Tehran: Company Press Ministry of Islamic Guidance.

Immanuel, K. (1990). Metaphysics foundation of ethics. Tehran: Khwarizmi Publishing.

Islami, Hasan, \& Imam. (2002). Ethics, politics. Tehran: The Institute for Compilation and Publication of Imam Khomeini's Works. 
Jahanbegloo, R. (1995). Modernity, democracy, intellectuals. Tehran: Markaz Publishing.

Mahmoudi, S. A. (1998). Harmony of ethics and politics. Culture Quarterly, 11(3/4).

Mesbah, Y., \& Mohammad, T. (1998). Law and Policy in the Quran. Imam Khomeini Education and Research Institute, Qom.

Mesbah, Y., \& Mohammad, T. (1999). Islamic political theory (for a country). Imam Khomeini Education and Research Institute publication, Qom.

Mesbah, Y., \& Mohammad, T. (2001). Islamic legal theory. Imam Khomeini Education and Research Institute, Qom.

Mesbah, Y., \& Mohammad, T. (2002). Religion and freedom. Cultural Studies and Research Center of Qom Seminary.

Mir, M., Seyed, A., \& Seyed, S. H. (2002). Human rights in the view of Islam and other schools. Knowledge and Contemporary Thought Cultural Institute, Tehran.

Mohammad, T., \& Mesbah, Y. (2007). Ethics principle. Tehran: International publishing companies.

Mohammad, T., \& Mesbah, Y. (n.d.). The response of master to the young questioners.

\section{Copyrights}

Copyright for this article is retained by the author(s), with first publication rights granted to the journal.

This is an open-access article distributed under the terms and conditions of the Creative Commons Attribution license (http://creativecommons.org/licenses/by/4.0/). 